\title{
Sustaining Competitive Advantage in Private Universities: A case study of Southern Region of Nigeria
}

\author{
Helen U. WARA ${ }^{1}$, Anthonia A. ADENIJI ${ }^{2}$, Ebeguki E. IGBINOBA ${ }^{3}$ \\ And Samuel T. WARA ${ }^{4}$ \\ ${ }^{1}$ Afe Babalola University, Ado-Ekiti, Ekiti State, Nigeria. \\ ${ }^{2,3}$ Covenant University, Ota, Ogun State, Nigeria. \\ ${ }^{4}$ College of Engineering, Afe Babalola University, Ado-Ekiti, Ekiti State Nigeria.
}

Correspondence should be addressed to: Helen U.WARA; helen.warapgs@stu.cu.edu.ng

Received date:18 Mai 2021; Accepted date: 17 July 2021 ; Published date: 12 October 2021

Academic Editor: B. Ake Modupe

Copyright (c) 2021. Helen U. WARA, Anthonia A. ADENIJI, Ebeguki E. IGBINOBA And Samuel T. WARA. Distributed under Creative Commons Attribution 4.0 International CC-BY 4.0

\begin{abstract}
s
A limited number of persons can afford the fees of private universities; hence, enrolment determines survival. The choice of those who can afford the fees depends on the institution's corporate reputation. In a service-providing organization, the development and sustenance of a strong brand is seen as the principal function of the Marketing and Corporate Affairs Unit. This practice relegates the employees of other departments in the drive for competitive advantage and corporate reputation. The objective of the study is to determine the effect of Employee-based brand equity (information generation and knowledge dissemination) on financial performance. The study adopted the quantitative research method, using the questionnaire as the research instrument. 700 questionnaires (soft and hard copies) were administered to six private universities' staff in the nation's southern region. The randomly selected respondents returned 594 copies of the questionnaires. The data collected were analyzed using the Structural Equation Model, specifically the Partial Least Square. The tested hypotheses revealed that information generation and knowledge dissemination have a significant effect on financial performance. The findings revealed that the perceived corporate reputation of the universities by the employees affected their relationship with the institutions' external customers. The study recommends that the managers of private universities should educate employees on institution's brand promise and establish a feedback mechanism that enables employees report their experiences on the field with external customers. Such feedback should be injected into the decision-making processes and individual knowledge should be institutionalized.
\end{abstract}

Keywords: Employee-Based Brand Equity, Corporate Reputation, Competitive Advantage, Private Universities

Cite this Article as: Helen U. WARA, Anthonia A. ADENIJI, Ebeguki E. IGBINOBA And Samuel T. WARA (2021)," Sustaining Competitive Advantage in Private Universities: A case study of Southern Region of Nigeria", The Journal of Organizational Management Studies, Vol. 2021 (2021), Article ID 675387, DOI: $10.5171 / 2021.675387$ 


\section{Introduction}

Universities can survive a competitive environment by creating dissimilar brand images from adopted strategies that could create competitive advantages. The choice of a private university for the limited number of candidates, their parents or guardians, depends on the reputation of the universities (Panda, Pandey, Bennet \& Tian, 2019). Universities must have enough students enrolment to be able to survive (Heer, 2020). The corporate reputation of the institution distinguishes the institution and determines the decisions or actions of the stakeholders (Akintaro \& Ekhareafo, 2017; Baumgartner, Ernst \& Fischer, 2020). In service-providing organizations like universities, the Admissions office and the Media and Corporate Affairs Units are seen as solely responsible for marketing universities' brands. The development and sustenance of a strong brand is equally seen as the principal function of the Marketing /Sales department in organizations (Alshuaibi, Shamsudin \& Aziz, 2016). Also, the building of corporate reputation is seen as the function of the Marketing and Public Relations department of organizations (Chun, Argandoña, Choirat \& Siegel (2019). The employees are overlooked by the managers of these institutions as possible advertisement outlets for their services/products and reputation building. Institutional goals can be achieved by maximally utilizing all operant resources, sharing individual competencies of employees to make them organizational competencies.

Guided by the concept of internal brand management, the challenge of private universities' competitiveness and corporate reputation might be addressed by Employee-based brand equity (EBBE). Internal brand management is a process that promotes the sharing of brand values amongst employees to ensure better representation of the brands by employees (Adamu, Abd Ghani \& Rahman, 2019). Employees' perception of an organization's reputation determines their motivation at work and attitude. These inadvertently affect the employees' communication with the external stakeholders (Amegbe, 2016; Esenyel, 2020).

EBBE refers to the translation of an organization's brand identity to an employee to enable him/her successfully deliver on the organization's brand promise through his/her job performance. The EBBE is suggested as a possible solution because it focuses on internal brand management using employees' of universities as asset /resources that can bring about a competitive edge and positive corporate reputation in the eyes of the external stakeholders.

\section{Statement of Research Problem}

Studies have been conducted on the corporate reputations and competitiveness of private universities and suggestions proffered on overcoming challenges faced by them (Adedeji, Okotoni \& Ogunleye, 2019; Oluwasanmi, 2016; Babatunde; 2017; Atanda, \& Adeniran, 2017, Ekeagbara, Ogunnaike, Ibidunni \& kehinde, 2019; Olawore \& Ajayi, 2016; Shamsudin,, Nurana, Aesya, \& Nabi, 2018). There are no studies on how employee-based brand equity can improve the corporate reputation of private universities. This study, therefore, concentrated on the effect of information generation (IG) and knowledge dissemination (KD) (some constructs of EBBE) on the perceived financial performance (FP) (a construct of corporate reputation) of private universities. IG is the perception of employees that the Management of the universities utilises the feedback generated from them in their decision-making process. On the other hand, KD refers to employees' empowerment with information that enables them to deliver on the brand promise (King \& Grace, 2009; Al-Shauaibi, Shamsudin \& Aziz, 2016). Researchers had investigated the impact of $\mathrm{KD}$ on organizational performance and concluded that organizations with a large spread of KD have better organizational performance (Eresia-Eke and Makore, 2015). However, it is important to note that studies have not examined how IG could influence the FP of private universities in Nigeria. Few studies 
examined the influence of knowledge dissemination on private universities' financial performance. This study aims at achieving the following objectives, to investigate the effect of:

i. information generation on financial performance; and

ii. knowledge dissemination on financial Performance.

Based on the problem statement, the researchers formulated the questions and hypotheses to guide the study with respect to how: i. information generation influence financial performance?; and

ii. knowledge dissemination influence financial performance?

\section{Research hypotheses:}

(i). $\mathbf{H}_{1}$ : information generation does not have a significant influence on financial performance.

(ii) H2: knowledge dissemination does not significantly influence financial performance.

\section{Conceptual model}

The conceptual model relating IG, KD and FP is as shown in Figure 1.

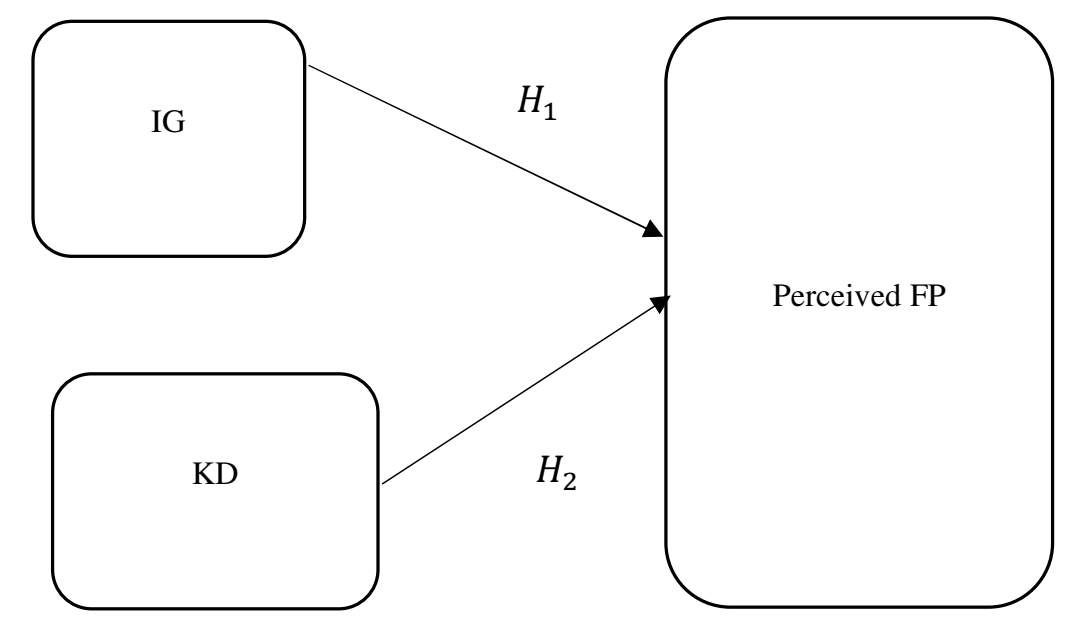

Figure 1: A Conceptual model of EBBE on Corporate reputation

\section{Literature Review}

\section{Corporate Reputation}

An organization's reputation is seen or perceived by both internal and external stakeholders. The internal stakeholders are the internal customers (employees), and the external stakeholders are the customers. According to Falola, Adeniji, Adeyeye, Osibanjo, Igbinoba and Salau (2018), "reputation is value judgement among the public about an organization's quality formed over time regarding its consistency, trustworthiness and reliability". The indicators of corporate reputation are vision and leadership, products and services, financial performance, social responsibility and emotional appeal.

\section{Employee-Based Brand Equity (EBBE)}

The provision of exceptional service (regardless of whether the organization's core product is a physical product or service) by employees is used as a weapon to gain a competitive edge against competitors (King \& Grace, 2009). EBBE refers to the translation of an organization's brand identity/brand value to an employee to deliver on the brand promise through 
his/her job performance. King and Grace (2009) defined EBBE as "the differential effect the knowledge of a brand has on an employee's response to their work environment".

\section{Internal Brand}

According to Ngo, Nguyen, Kuynh, Gregory and Pham (2019), internal branding influences employees' attitude and behaviour to align with brand values through a proper comprehension of the brand values. Organizations are responsible for delivering promised benefits of brands to customers. The delivery of that responsibility depends on employees' ability to develop functional and nonfunctional services that distinguish their offerings from their competitors' behaviour towards customers (Piehler, Grace, \& Burmann, 2018). Quality Service gives organizations an edge over their competitors (. Enaworu, Adegboye \& Wara, 2018).

In the contact service industry like the university setting, where delivery of service entails contacts with customers by the employee, the employee behaviour affects the customers' perception of the brand, service quality and ultimately the satisfaction level, which further decides future patronage and referrals to other customers (King, 2008).

\section{Information Generation (IG)}

The deliberate gathering of information of employees needs on their jobs and assurance from Management that they can be open, makes employees realise their importance. However, the availability of information is onlypresent in an environment where Management acknowledges and supports employees' efforts (Amangala and Amangala (2013). Organizations that pay attention to feedback from employees can generate relevant information that can move the organization forward. King and Grace (2010) refer to IG in this context as the level to which employees perceive the use of feedback from them in the organization's decision-making process. If feedback is taken, the organization's shortcomings on the field in their interaction with external stakeholders are corrected, making for better products and services and, eventually, better patronage.

\section{Knowledge Dissemination (KD)}

The use of specific employees with special skills to secure competitive advantage is outdated. The shared knowledge of the good few's, puts the organization in a better position to secure a competitive advantage. (Agbim \& Idris, 2016). The acquisition of knowledge by employees starts with selecting the right information from within and outside the organization (co-workers and customer feedback). The appropriate application of such information to an employee's job activity contributes to the organization's performance (Xiong \& King, 2019). Therefore, managers of a system must manage knowledge appropriately by ensuring that individual knowledge is transformed into organizational knowledge. King and Grace (2009) defined $\mathrm{KD}$ as "the extent to which an employee perceives brand knowledge is transferred from the organization to the employee, in a meaningful and relevant manner". The discovery of a knowledge/tool or experience that has improved a unit's performance should be communicated to other units /departments in an organization.

\section{Financial Performance (FP)}

Financial performance indicates how an organization is utilizing its resources to maximize the shareholders' wealth and profitability. FP is the measurement of an organizations financial well-being over some time. The process manages an organization's current and non-current assets, financing, equity, revenues, and expenses, resulting in increased sales, profits, and overall worth of the business to the benefit of the shareholders. In addition, this process evaluates comparable organizations of the same industry and provides information that makes decisionmaking easier for the shareholders and stakeholders (Naz, Ijaz \& Naqvi, 2016).

There are, however, studies that had been done in the past on the perception of FP by 
employees. It is a general notion that the actual state of the affairs of an organization is never out for public consumption. An employee who has a very poor perception of the financial state of an organization is taunted by insecurity, which would affect his/her commitment to external stakeholders. According to Özbağ and Çekmecelioğlu (2019), the perception of the reputation of an organization by an employee is crucial. An organization's most significant reputation leverage is realised through employees, and their perception also shapes external corporate reputation.

\section{Theoretical Review}

\section{Resource-Based Theory (RBT)}

Resource-Based Theory (RBT) is centered on the notion that the ability of an organization to make judicious use of all available resources, especially human resources, effectively and efficiently will enable such an organization gain and sustain a competitive advantage. RBT is premised on two assumptions in explaining competitive advantage: that the resources controlled by firms within an industry may be heterogeneous and the variedness of the resources are not so mobile, difficult to accumulate and imitate as such the resource heterogeneity persists over time (Kozlenkova, Samaha \& Palmatier, 2013. Pee and Kankanhalli (2016) state that resources, especially human resources, are a major key to a firm's performance. All significant resources that contribute to a firm's competitive advantage and eventual market performance must be acknowledged and their contributions measured (Duh \& Uford, 2019). Also, though the mind and emotions are needed to align employees' behaviour with the brand promise (Itam \& Singh, 2016), the Human Associative memory theory was not introduced into the study but the Social Exchange Theory (SET).

\section{Social Exchange Theory}

Social exchange theory was introduced in 1958 by George Homans in his work "Social Behaviour as Exchange". The basic foundation of social Exchange Theory is reciprocity. It refers to a relationship between two or more parties based on voluntary actions of reciprocity. According to Blau (1964), Social Exchange Theory involves voluntary behaviours exhibited by individuals generated through social interactions. The parties' compliance in the relationship to the "rules" of exchange evolves into mutual commitment, loyalty and trust. The social exchange theory begins with a party providing input into a relationship for exchange from the same relationship (Cropanzano \& Mitchell 2005)

\section{Methodology}

\section{Research Design, Data collection and analyses}

Data were collected using google form (soft) and hard copies of questionnaires from the academic and non-academic staff of six selected private Universities in the Southern region of Nigeria. The research used a descriptive research design, purposive and stratified sampling to ensure all sub-groups under study were adequately represented.

Seven hundred (700) questionnaires were distributed to the selected universities. Five hundred and ninety-four (594) questionnaires were correctly filled and returned. The measurement of the chosen constructs of EBBE (IG and KD) and corporate reputation (financial performance) was adapted from King and Grace (2010) and Özbağ and Çekmecelioğlu (2019) respectively. The constructs were measured using the four-point Likert scale, where $4=$ strongly disagree and $1=$ disagree. The EBBE constructs had seven (7) items each, while the corporate reputation construct had three (3) items. The reliability of the measures was tested before the distribution of the questionnaires. The scales came back reliable, meeting the recommended threshold of 0.7 and above. The partial least square (PLS) structural equation modeling using the Smart PLS software, version 26, was used to test the hypotheses. 


\section{Results}

\section{Descriptive Statistics}

The descriptive statistics showed there were more males $(67.3 \%)$ than females $(32.7 \%)$, indicating male employees' dominance. Furthermore, the age distribution showed that $0.7 \%$ of employees were less than 21 years old. Also, $93 \%$ of the employees were within the active economic age range of $22-54,4.4 \%$ were in the range of $55-65$, and $1.9 \%$ were $65 y$ ears and above. Furthermore, $66 \%$ of the population had postgraduate degrees, $24.7 \%$ were degree holders, 7\% were National Diploma holders, and $2.2 \%$ were School Certificate holders.
Finally, $88 \%$ were full-time staff, $3.4 \%$ contract staff, while $8.2 \%$ were casual staff; it was observed that $52.9 \%$ were Academic Staff, $47.1 \%$ were non-academic staff.

\section{Measurement Model}

The measurement model tested the construct reliability, validity, and model fit, as shown in Tables 1,2, $3 \& 4$ ). All the constructs had acceptable reliability, with composite reliability ranging between 0.8 to 0.9 and within the threshold of 0.7. In addition, factor loading and average variance extracted were all acceptable with figures greater than 0.05 .

Table 1: Construct Validity and Reliability for $\mathrm{H}_{1}$

\begin{tabular}{|c|c|c|c|c|c|c|c|}
\hline & $\stackrel{60}{: 0}$ & $\stackrel{s}{\supset}$ & 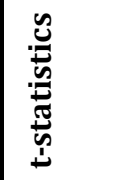 & $a \stackrel{\frac{0}{ٍ}}{\frac{\pi}{\nu}}$ & $\sum^{5}$ & 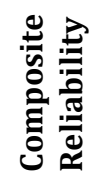 & 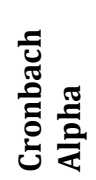 \\
\hline Constructs & $\geq 0.7$ & $<3.0$ & $>1.96$ & $<.05$ & $\geq 0.5$ & $\geq 0.8$ & $>0.7$ \\
\hline \multicolumn{4}{|c|}{ Information Generation (IG) } & & 0.659 & 0.905 & 0.867 \\
\hline IG1 & 0.889 & 2.276 & 66.265 & 0.000 & & & \\
\hline IG2 & 0.866 & 2.089 & 30.677 & 0.000 & & & \\
\hline IG3 & 0.638 & 1.325 & 7.991 & 0.000 & & & \\
\hline IG4 & 0.826 & 2.491 & 23.177 & 0.000 & & & \\
\hline IG5 & 0.815 & 2.224 & 19.678 & 0.000 & & & \\
\hline \multicolumn{3}{|c|}{ Financial Performance (FP) } & & & 0.754 & 0.902 & 0.839 \\
\hline FP1 & 0.866 & 1.809 & 24.567 & 0.000 & & & \\
\hline FP2 & 0.835 & 2.002 & 19.753 & 0.000 & & & \\
\hline FP3 & 0.904 & 2.298 & 54.145 & 0.000 & & & \\
\hline
\end{tabular}

Table 2: Path Coefficients for IG (IG) and Financial Performance (FP)

\begin{tabular}{|ll|c|c|c|c|c|}
\hline & $\begin{array}{c}\text { Path } \\
\text { Coefficient }\end{array}$ & R-Square & Std. Dev & T-statistics & P-value \\
\hline IG $\Rightarrow$ FP & 0.604 & 0.365 & 0.070 & 8.623 & 0.000 \\
\hline
\end{tabular}


Table 3: Construct validity and Reliability for $\mathrm{H}_{2}$

\begin{tabular}{|c|c|c|c|c|c|c|c|}
\hline & 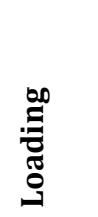 & 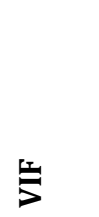 & 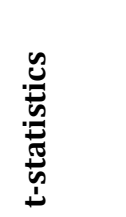 & a & 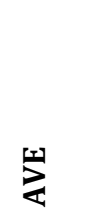 & 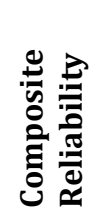 & 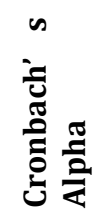 \\
\hline Constructs & $\geq 0.7$ & $<3.0$ & $>1.96$ & $<.05$ & $\geq 0.5$ & $\geq 0.8$ & $>0.7$ \\
\hline & \multicolumn{3}{|c|}{ Knowledge Dissemination (KD) } & & 0.542 & 0.853 & 0.799 \\
\hline KD1 & 0.730 & 2.581 & 9.720 & 0.000 & & & \\
\hline$\overline{\mathrm{KD} 2}$ & 0.853 & 1.941 & 26.388 & 0.000 & & & \\
\hline KD3 & 0.811 & 2.911 & 17.751 & 0.000 & & & \\
\hline KD4 & 0.604 & 1.654 & 6.538 & 0.000 & & & \\
\hline KD5 & 0.653 & 1.414 & 9.930 & 0.000 & & & \\
\hline \multicolumn{3}{|c|}{ Financial Performance (FP) } & & & 0.755 & 0.902 & 0.839 \\
\hline FP1 & 0.871 & 1.809 & 28.377 & 0.000 & & & \\
\hline FP2 & 0.845 & 2.002 & 20.935 & 0.000 & & & \\
\hline FP3 & 0.890 & 2.298 & 29.746 & 0.000 & & & \\
\hline
\end{tabular}

Table 4: Path Coefficients for Knowledge Dissemination (KD) and Financial Performance (FP)

\begin{tabular}{|l|c|c|c|c|c|}
\hline & $\begin{array}{c}\text { Path } \\
\text { Coefficient }\end{array}$ & R-Square & Std. Dev & T-statistics & P-value \\
\hline KD $\Rightarrow$ FP & 0.647 & 0.418 & 0.062 & 10.362 & 0.000 \\
\hline
\end{tabular}

\section{Hypotheses Testing Results}

The tested $\mathrm{H}_{1}$ and $\mathrm{H}_{2}$ showed the effect of IG and $\mathrm{KD}$ on perceived financial performance.

The finding showed that IG had a significant effect on financial performance at $(\beta=$ $0.604, \mathrm{R}^{2}=0.365$, t-statistics $=8.623>1.96$, $\mathrm{P}$-value $=0.000<0.01$ ). The Path coefficient of 0.604 suggests a significant strength of the relationship between IG and FP. The $\mathrm{R}^{2}$ value of 0.365 indicates that IG can explain a $36.5 \%$ variance in FP. The null hypothesis was therefore rejected.

The finding also showed that KD had a significant effect on FP at $\left(\beta=0.647, \mathrm{R}^{2}=\right.$ $0.418, \mathrm{t}$-statistics $=10.362>1.96, \mathrm{P}$-value $=$ $0.000<0.01$ ). The Path coefficient of 0.647 suggests a considerable and significant strength of the relationship between $\mathrm{KD}$ and FP. The $\mathrm{R}^{2}$ value of 0.418 indicates that KD can explain a $41.8 \%$ variance in FP. The null hypothesis was also rejected.

\section{Discussions and Implication}

The relationship between IG and FP in the selected private universities was directly significant, with a beta value of 0.604 , indicating a moderate degree of relationship. The analysis showed that the indicators of IG variables substantially explained $36 \%$ of the change of FP in the selected private universities. In other words, $36 \%$ of the change in FP was due to the model's five latent constructs, suggesting good explanatory power for the model. The results statistically indicated that the measures of IG significantly influenced perceived FP. A further look at the measures of IG indicated that the EBBE was influenced considerably by data gathered from employees to improve their 
jobs, followed by the Management's meetings with employees, then direct interaction of employees with Management. The IG measure with the most negligible value was the staff Appraisal exercise, where employees' wants were discussed. The implication of what is displayed in the result is that the universities should implement policies that encourage employee feedback, which should be adapted when found to be good. Also, policies that encourage meetings where employees' expectations for the future are discussed and their expectations met should be in place. The result showed that the discussion of what employees want only at the Staff appraisal period would not yield as much effect as the other measures on FP.

The findings of this study is supported by the works of Özbağ and Cekmecelioğlu (2019), which substantiated the fact that perceived corporate reputation of institutions by employees (middle and top managers) in terms of IG had a positive effect on quantitative performance and overall qualitative performance.

The result is also supported by the work of Neerja and Vandana (2017). They stated that internal communication between employees and the employer (the Management) could improve employee behaviour and strengthen brand value leading to financial benefits.

If the result should be inferred in this study, IG in the institution affects the employee's perception of FP of the institution. A positive perception of the employees about IG would result in commitment and a qualitative relationship with external customers, resulting in increased patronage (quantity) and eventually increased FP.

Findings from the analysis showed that KD had significant effects on FP. The relationship was confirmed to be directly significant with a beta value of 0.647 , indicating a strong degree of association. All path coefficients were of practical importance since the significance level was below 0.05. The result suggests that employees' skill and knowledge development, as an ongoing process, had the highest beta values among the constructs that best predict FP. The analysis showed that the independent variable (KD) indicators substantially explain $41.8 \%$ of the variability of financial performance in the selected Universities. This means that $41.8 \%$ of the FP change was due to seven latent constructs suggesting good explanatory power for the model. The relationship between $\mathrm{KD}$ for the selected institutions and FP was confirmed to be directly significant. By implication, the results established that KD had a significant predicting role on $\mathrm{FP}$. the measures of $\mathrm{KD}$ significantly contributed to the FP of the selected private universities.

A critical look at the measures of the $\mathrm{KD}$ showed that the EBBE was significantly influenced by an ongoing skill and knowledge development, followed by teaching employees why they should do things the way they were asked to do it and the communication of brand promise to employees. A continuous training/retraining/dissemination of skills and knowledge to old and new employees was effective and increased perceived FP. The results implied that some policies encourage the education of employees on the universities brand promise.

This study is supported by Eresia-Eke and Makore (2015) work that investigated the relationship between KD and organizational performance. Their results showed that there was a positive relationship between $\mathrm{KD}$ and organizational performance. This result of the study is also supported by the work of Agbim and Idris (2015). They investigated the relationship between Competitive advantage and KD. They stated that there was a significant relationship between KD and the competitive advantage of firms. Furthermore, the investigation revealed that the sustained competitiveness of the organizations investigated is traceable to disseminating knowledge amongst the organization's employees.

The findings have shown that there was a significant relationship between KD and FP. This means that the dissemination of knowledge practices was one of the key activities within an organization for boosting the employees' performance, which would invariably affect the 
organization's FP. Therefore, strategies that facilitate KD should be encouraged. The Universities should create formal and informal environments which enable employees to share knowledge.

This study supports the Resource-based theory in justifying the EBBE effect on the perceived corporate reputation of the universities. The resource of the universities, the employees, were concentrated on as assets that can bring about a considerable corporate reputation. Therefore, the Management of the universities should provide adequate information generated from the field based on the employees' experience, disseminate such information to all institution's employees, educate them on brand knowledge and their role. This will raise brand commitment, establish a work environment that allows continuous dialogue between employees, and ensure policies that portray the institutions have a human face in their dealings with the employees.

This study confirms the voluntary actions of reciprocity in the social interaction between employees and the university management. As described by the social exchange theory, the two-way relationship between the employees and the university's Management is evident.

\section{Recommendation}

Private universities should establish a feedback mechanism where employees can report their experiences with external stakeholders. Furthermore, the management should utilise them in their decision-making process. This will spur a sense of belonging and importance in the employees towards the system. Finally, private universities should institutionalise individual knowledge through staff training processes for a better competitive advantage.

\section{Conclusion and Limitations}

The study provided empirical evidence between EBBE (IG, KD) dimensions and perceived corporate reputation (financial performance). It expanded on EBBE literature related to private sector participation in education. It also enlightened the managers of private universities to the importance of their employees cum stakeholders as a vital catalyst for securing competitive advantage, strengthening their brand and corporate reputation (s).

This study was carried out on selected private universities in the Southern region of Nigeria, further research could be conducted on private universities in other parts and longitudinal research may be conducted.

\section{Acknowledgement}

This paper is sponsored by Afe Babalola University Ado Ekiti, Nigeria for publication in Journal of Organizational Management Studies.

\section{References}

- Adamu, L., Abd Ghani, N.H. and Rahman, M. A. (2019). 'The Internal Branding Practices and Employee-Brand Citizenship Behaviour: The Mediating Effect of Employee Brand Fit,' Journal of Environmental Treatment Techniques, 8 (1), 99-106.

- Adedeji, S.O., Okotoni, C.A. and Ogunleye, A.O. (2019), 'Access and Quality of Private University Education in South-Western Nigeria,' US-China Education Review B, 9 (1). 21-33.

- Agbim, K.C. and Idris, A.J. (2016), 'Competitive Advantage through Knowledge Dissemination: An Empirical Analysis of Hotels in Makurdi Metropolis, Benue State Nigeria,' European Journal of Business and Innovation Research, 3 (1), 22-35.

- Akintaro, G.M. and Ekhareafo, D.O. (2017), 'An Evaluation of Reputation Management in Selected Federal Universities in South-West Nigeria,' 
Covenant Journal of Communication (CJOC), 4 (1), 53-65.

- Al-Shuaibi, A. S. I., Shamsudin, F. M. and Abd Aziz N. (2016), 'Developing Brand Ambassadors:TheRole of Brand Centre HRM,' International Review of Management and Marketing, 6 (7S), 155-161.

- Amangala, T.A. and Amangala, E. A. (2013), 'Effects of Internal Marketing and its Components on Organisational Level Customer Orientation: An Empirical Analysis,' European Journal of Business and Management, 5 (8), 64-73.

- Amegbe, H. (2016), 'Internal Branding and the Competitive Performance of Private Universities in Ghana,' Journal of Competitiveness. 8 (3), 22-37.

- Atanda, I. A. and Adeniran F.A. (2017), 'Towards the Effective Management of Private University Education in Nigeria,' International Journal of Advanced Academic Research Arts Humanities and Education,' 3 (3), 7-24.

- Babatunde, M.M. (2017), 'Era of Economic Recession in Nigeria: Impacts and Survival Strategies for Managing Private Universities,' International Journal of Humanities and Social Development Research, 61-72.

- Baumgartner, KT., Ernst, C.A. and Fischer, T.M. (2020), 'How Corporate Reputation Disclosure Affects Stakeholders' Behavioural Intention: Mediating Mecahnisms of Perceived Organizational Performance and Corporate Reputation,' Journal of Business Ethics. Httpps://doi.orf/10.1007/s10551020-04642-x.

- $\quad$ Chun, R., Argandoña, A., Choirat, C. and Siegel, D.S. (2019), 'Corporate Reputation: Being Good and Looking Good,' Business \& Society. 58 (6), 11311142.

- Cropanzano, R. and Mitchell, M. (2005), 'Social Exchange Theory: An Interdisciplinary Review,' Journal of Management, 31, 874-900. $10.1177 / 0149206305279602$.

- Duh, H.I. and Uford I. C. (2019), 'Examining Contributions of CustomerBased and Employee-Based Brand Equity to a Retail Bank's Market
Performance using the Resource-Based Theory,' Retail and marketing review 15 (1), 27-38.

- Ekeagbara J. A., Ogunnaike, O. 0., Ibidunni, A. S. and Kehinde, B. E. (2019), 'Competitive Strategies in Higher Education: Scale Development,' Review of Economics \& Business Studies 12 (1), 79-93.

- Enaworu, E, Adegboye, F.B. and Wara, H.U. (2018), 'Competitiveness in Banking Industry: A Study of Employee Satisfaction, Customer Satisfaction and Productivity in Service,' Khajeheian, D., Friedrichsen M. \& Modinger, W. (Ed.), Competitiveness in Emerging Markets, (373-390), Springer international.

- Eresia-Eke, CE and Makore, S. (2015), 'The Relationship between Knowledge Dissemination and Organisational Performance in The Construction Industry,' The Scientific Journal for Theory and Practice of Socio-economic Development, 4 (8): 477-492.

- Esenyel, V. (2020), 'The Influence of Corporate Reputation on Affective Organizational Commitment: The Role of Value Congruence as Mediator,' International Journal of Organizational Leadership, 8 (2019) 60-70.

- Falola, H.O., Adeniji, A.A., Adeyeye, J.O., Osibanjo, A.O., Igbinoba, E.E. and Salau O.P. (2018), 'Corporate Image And Customers' Behavioural Outcomes in the ICT Inclined Hospitality Industry in Nigeria,' International journal of Mechanical Engineering and Technology, 9 (13), 854-864.

- Heer, D. F. (2020). 'Exploring the Understanding of University Brand Equity: Perspectives of Public Relations and Marketing Directors.' Journal of Business and Management, 22 (7), 4957.

- Itam, U. and Singh S. (2016), 'Exploring the Link between Corporate Branding and Employee Engagement: An Interdisciplinary Approach,' International Journal of Business Management, 4 (1), 150-160.

- King, C. (2008), 'Building EBBE: Model Conceptualisation and Development. Thesis (Phd Doctoral),' Retrieved, November, 2018 from https://www120.secure.grffith.edu.au 
/rch/item/ c5363246-d3bf-aad1-4le27950aaf9afe7/1/

- King, C. and Grace, D. (2009), 'Employee-Based Brand Equity. A Third Perspective,' Service Marketing Quarterly, 30 (2), 122-147. DOI: $101080 / 15332960802619082$

- $\quad$ King, C. and Grace, D. (2010), 'Building and Measuring Employee-Based Brand Equity,' European Journal of Marketing, 44 (7/8), 938-971.

- Kozlenkova, I. V., Samaha, S.A. and Palmatier, R.W. (2014), 'ResourceBased Theory in Marketing,' Academy of Marketing, 42, 1-21.

- Naz, F., Ijaz, F. and Naqvi, F. (2016), 'Financial Performance of Firms: Evidence from Pakistan Cement Industr,' . Journal of Teaching and Education, 5 (1), 81-94.

- Neerja, K. and Vandana, T.K. (2017). 'Building Employee Brand Equity to Influence Organizational

- Attractiveness and Firm Performance, International Journal of Business and Management, 12 (2), 207219.

- Ngo, L.V., Nguyen P. N., Kuynh, K.T., Gregory G. and Pham H.C. (2019), 'Converting Internal Brand Knowledge into Employee Performance, Journal of Product and Brand Management, Emerald Publishing Limited [ISSN 1061-0421] [DOI 10.1108/JPBM-10-2018-2068.

- $\quad$ Olawore, O.P. \& Ajayi, T.B. (2016), 'The Emergence of Private Universities in Nigeria and their various Challenges,' Journal of Applied Information Science and Technology, 9 (1), 31-38.

- Oluwasanmi, 0.0. (2016), 'Determinants of Students Choice of Private Universities in Nigeria: A
Corporate branding perspective,' AlHikmah Entrepreneurial Journal of Management Sciences, 5 (1), 87-97.

- Özbağ, G.K. and Çekmecelioğlu, H.G. (2019), 'Examining the Effects of Dimensions of Corporate Reputation on Firm Performance,' The European Proceedings of Social \& Behavioural Sciences, https://dx.doi.org/10.15405/epsbs.20 19.01.02.24.

- Panda, S., Pandey, S.C., Bennett A. and Tian, X. (2019), 'University Brand Image as Competitive Advantage: A two Country Study,' International Journal of Education Management, 33 (2), 234251.

- $\quad$ Pee, L.G. and Kankanhalli, A. (2016). Interactions among Factors Influencing Knowledge

Management in Public-Sector Organizations: A Resource-Based View. Government Information Quarterly, 3 (1), 188-199.

- Piehler, R. Grace, D. and Burmann, C. (2018), 'Internal Brand Management: Introduction to the Special Issue and Directions for Future Research,' Journal of Brand Management, 25, 197-201.

- Shamsudin, M.F., Nurana, N., Aesya, A. and Nabi, M.A. (2018), 'Role of university reputation towards student choice to private universities,' Opcion 34 (16), 285-294

- Xiong, L. and King, C. (2019),' Aligning the Employees' Attitude and Behaviour with Hospitality Brands: The Role of Employee Brand Internalisation,' Journal of Hospitality and Tourism Management, 40, 67-76. 